\title{
Inquiry Beliefs and Practices in an Urban Low SES Elementary Classroom: A Case Study
}

\author{
Boby Jeanpierre \\ University of Central Florida, USA
}

\begin{abstract}
This case study explored the inquiry beliefs and practices of an elementary teacher in an urban low SES school. The case study included an array of data collection methods: teacher interview, classroom observations of teacher's practices (3-5) days a week over six months, weekly journal reflections, teacher's responses to an inquiry survey, responses to the Excellent Science Teaching Educational Evaluation Model survey and the school-level principal was interview about her perceptions of the teacher's science instructional practices. Findings indicated that the teacher's beliefs and practices did align and that she did consistently use structured and guided inquiry practices, but rarely used "full inquiry" as described in the National Science Education Standards. Key to this teacher's use of inquiry was the professional education she had received that both modeled and provided opportunity for her to use various inquiry practices. She also had a belief that all of her students deserved to have quality science experiences and that she could provide it best through inquiry. She sought to increase students' interest in and experiences with doing science. Time was sometimes a hindrance to the completion of inquiry activities and inquiry-based curricula materials were also important to facilitating the teacher's use of inquiry.
\end{abstract}

Keywords: Science, urban, elementary

\section{Introduction}

The new Framework for K-12 Science Education (NRC, 2011) has integrated inquiry and describes eight practices in science and engineering. Five of the eight practices are integral to inquiry. They include: asking questions, planning and carrying out investigations, analyzing and interpreting data, conducting experiments and obtaining, evaluating and communicating information. It is important to understand that the practices do not abandon inquiry but seek to inform science teaching and learning based on insights gain from recent science education research and lessons learned from standards implementation.

The need to examine teachers' day-to-day science inquiry practices and their beliefs remain relevant to the improvement of K-12 science teaching and learning. There is still a lot we do not know about quality inquiry instruction. In fact, there is a gap in what is known about why teachers decide to use inquiry and how they enact it in their classrooms. Researchers support the need to learn more about the inquiry perspectives of pre-service and in-service teachers in the field (Pennuel \& Fishman, 2012; Keys \& Bryan, 2001). Additionally, we know even less about why teachers in low SES urban science classrooms choose to use inquiry. Therefore, it is apparent that more research, which describes teachers' classroom practices and reasons for doing inquiry in low SES urban settings is needed. This research aimed to address this gap in the literature using a case study

${ }^{1}$ Corresponding author. School of Teaching, Learning and Leadership \& Department of Educational Human Sciences, College of Education, University of Central Florida, PO Box 161250 Orlando, FL 32816, E-mail: bobby.jeanpierre@ucf.edu

Jeanpierre, B. (2018). Inquiry Beliefs and Practices in an Urban Low SES Elementary Classroom:A Case Study. Journal of Research in STEM Education, $4(2), 146-158$. 
investigation of an elementary teacher's beliefs about inquiry and how she implemented it in an urban low SES classroom.

This manuscript presents rich descriptive case study findings obtained from the first teacher selected to participate in this longitudinal study. Documented below are descriptions of the first case study teacher, Martha, her inquiry beliefs, practices and lessons learned as she carried out inquiry science lessons with her fifth grade students. Next is the literature review and conceptual framework for the study.

\section{Literature Review and Conceptual Framework}

Inquiry has a long history in science and science education literature. For example, Dewey (1910) advocated that children experience science and not be passive recipients of ready-made knowledge. He contended that knowledge is "not information, but a mode of intelligent practice and a habitual disposition of mind" (p.124). Schawb (1962), in "The Teaching of Science as Enquiry" echoed Dewey's sentiments on the importance of inquiry-based teaching and learning. He stated:

In the very near future a substantial segment of our public will become cognizant of science as a product of fluid enquiry, understand that it is a mode of investigation, which rests on conceptual innovation, proceeds through uncertainty and failure, and eventuates in knowledge which is contingent, dubitable, and hard to come by (p. 5).

Inquiry has been heralded as essential to student development of what Dewey (1910) called habits of mind- way of thinking that promotes scientific reasoning skills. The inclusion of inquiry is a constant in science education. The K-12 Framework for Science Education: Practices, Crosscutting Concepts and Core Ideas (NRC, 2011) supports inquiry. The National Science Education Standards emphasized the need for teachers to implement more "inquiry-based" science teaching and learning opportunities. In fact, in the NSES (1996), inquiry is viewed as the key strategy to effective science teaching. "Inquiry into authentic questions generated from student experiences is the central strategy for teaching science" (p. 31). The National Science Education Standards support that when children inquire into the natural world they: 1) ask questions, 2) plan investigations and collect relevant data, 3) organize and analyze collected data, 4) think critically and logically about relationships between evidence and explanations, 5) use observational evidence and current scientific knowledge to construct and evaluate alternative explanations, and 6) communicate investigations and explanations to others." This is only one of a myriad of definitions of inquiry and other well-noted sources exist. For this study, the National Science Education Standards (1996) definition of inquiry was used to help frame the context of how inquiry teaching was represented in the case study classrooms.

Scientific inquiry refers to the diverse ways in which scientists study the natural world and propose explanations based on the evidence derived from their work. Inquiry also refers to the activities of students in which they develop knowledge and understanding of scientific ideas, as well as an understanding of how scientists study the natural world (p. 23).

In contrast to this perspective on inquiry is that in many instances workbooks and textbooks dictate what science instruction occurs in the classroom. Huber and Moore (2001) argued that unfortunately, handson activities recommended by science textbooks and worksheets are typically presented as step-by-step instructions. If a step-by-step approach is followed, it may not foster inquiry practices. Teachers' use of inquiry methods maybe linked to their beliefs and practices.

Researchers have provided a strong literature foundation for the importance of teachers' beliefs (Lotter, Dickenson, Blue, \& Rea, 2018; Kaymakamoglu,, 2018; Nespar, 1987; Richardson, 1996; Pajares, 1992; Parke \& Coble, 1997; Bryan \& Abell, 1999; Abell \& Smith, 1992; Haggerty, 1992; Hewson \& Hewson, 1989; Jasalavich, 1992; \& Lorsbach, 1992), which revealed that they are central to their classroom practices. The importance of a teacher's beliefs is situated within the context in which teaching and learning occurs. Teachers' beliefs as related to the abilities of urban learners are also important for they may affect what they do in the classroom. 
How teachers perceive their role as science teachers may have profound effects on what they do (O'Laughin, 1991). And other researchers suggest that, "Beliefs are not easily changed. Brand and Glason (2004) argue that the more important a belief is, the more resistant it is to change.

Urban classrooms can hold distinct challenges for teachers desiring to teach using learner-centered practices (Leonard, Barnes-Johnson, Dantley, and Kimber, 2011). It is a welcome occurrence when urban elementary teachers, embrace science reform instructional practices, like inquiry. Additionally, urban science classrooms are particularly complex cultural interface zones in that the cultures interacting are not only those of the students and teachers but also that of science as an intellectual discipline" (Norman, Ault, Bentz \& Meskimen, 2001, p. 1103). Elementary science instruction matters even more in large urban settings given the huge number of obstacles these students face. In fact, Lawrenz, (1986) argued that if “elementary students aren't exposed to quality science education in their beginning years; they may be at a significant disadvantage" ( $\mathrm{p}$. 654). Rist (2017) goes even further and argues that "The ability of the schools to generate social and economic opportunity for this massive group of children when the rest of the social structure works to block their way onto the mobility escalator is simply quite limited" (p.15). Rist's observation about America's urban schools only increases the need for high quality teaching in these schools.

With the importance that the National Science Education Standards place on students experiencing inquiry learning in schools, and the fact that we need to learn more about teachers' views about the goals and purposes of inquiry, and the processes by which they carry out inquiry (Keys \& Bryan, 2001) increases the importance of how inquiry is enacted in low SES urban school settings. The lenses provided for organizing and categorizing findings of the study were presented in the literature and conceptual framework and situated in the importance of teacher's inquiry beliefs and practices.

\section{Research Questions}

1. What were Martha's beliefs about inquiry?

2. How did Martha facilitate inquiry?

\section{Methods}

A case study method was used to conduct this research. A case study, as defined by Yin $(1989 ; 2015)$, is an empirical inquiry into real-life context in which multiple sources of evidence are used. The school selected for this study was an urban low SES elementary prek-5 school with $50 \%$ or more of students on the free-and reduced lunch program. Martha taught at this low SES school and reported on her inquiry beliefs survey that she taught science regularly, which met the main criteria for the study. She accepted the invitation to participate in the study.

The case study school, Loyola Elementary School was located in a large southeast urban school district and had 746 K-5 ethnically diverse students. Of those students 415 (55.6\%) were Hispanic, 190 (24.5\%) were Caucasian, 86 (11.5\%) were African American, 25 (3\%) were Asian and 30 (4\%) were classified as other. Of the 746 students, $533(72.9 \%)$ received free and reduced lunch. One-hundred and twenty-four (16.6\%) of the students received Education for Students with Exceptionalities services and 211 (28.3\%) received English Speaking Students of Other Languages services.

Over six months, multiple sources of qualitative data were collected. The data sources included: three to four days weekly classroom observation field notes that were video and audio taped, an inquiry beliefs and practices survey; a survey on constructivist beliefs "Excellent Science Teaching Educational Evaluation Model” developed by Burry-Stock (1991), teacher interview, teacher journal notes, and a principal's interview. This case study elucidated important findings about Martha's beliefs and her actual day-to-day inquiry practices in an urban low SES elementary science classroom. 


\section{Data Analysis}

The case study resulted in the compilation of rich, thick field notes that described the teacher's inquiry beliefs and practices. The data were triangulated across the fore stated multiple sources of data and then analyzed for recurrent themes and patterns, which were reported in this manuscript. From the diverse methods described, a rich thick descriptive case study of Martha's beliefs and practices was constructed. Pseudonyms were used throughout the manuscript for participants in the study and the elementary school.

\section{The Case Study}

\section{Martha's Class Demographics}

The fifth grade students in this study were part of a self-contained classroom of 21 students. Of these 21 students, 9(42.8\%) were boys and 12 (57.1\%) were girls. Nine (42\%) Hispanic, 8 (38\%) Caucasian, 3(14.2\%) African American and 1(4.7\%) were Asian. Approximately, twenty-three per cent of students received free and reduced lunch and $43 \%$ were classified as ESE and $9.5 \%$ were ESOL.

\section{Martha - Who she is and why she Uses Inquiry Science}

Martha, a Caucasian female taught fifth grade at Loyola Elementary School. She was in her sixth year of teaching and has certification in elementary education and ESOL. She provided the following details of her professional teaching preparation and why she uses inquiry.

My undergraduate work was split between two colleges. I began in south Florida at a private college, and then transferred to a public college in Massachusetts where I earned a BS in Elementary Education. During undergraduate work, I took one science methods class. I successfully completed both the Massachusetts and Florida teacher certification exams to become an elementary teacher.

Teaching science as inquiry was a gradual process born out of necessity. In my fourth year of teaching I moved to Massachusetts where I took a position as a fifth grade teacher in a middle school. After accepting the position, I learned I would be responsible for teaching science to the fifth graders. Wanting to be successful I had to begin to revamp my teaching. Until this point, science teaching consisted of assigning reading from the text and asking questions as dictated in the teacher's manual. I had neither significant science knowledge nor any desire to enhance my understanding. I was scared of teaching science because I did not believe I understood the topics well enough to answer any questions the students may have posed. I did not want to seem uneducated by my students, their families, or my colleagues but I really did not know what to do.

I started in small ways. I read the science text and I tried the activities outlined in it. Little by little my confidence grew, as did my understanding of the science concepts. After a year, I moved to a new state and took a position teaching k-5 science. At this point I knew textbook reading was not providing a quality experience for the students, but I was not familiar with science as inquiry. I began the year doing what I knew, activities from the text. Almost simultaneously two significant events introduced me to science as inquiry. I attended a week long professional development workshop where I was introduced to 5E inquiry. The workshop was significant because in additional to being introduced to a successful teaching methods, I was given the opportunity to participate in the inquiry process with other teachers and I was provided lessons that used inquiry based instruction. The workshop allotted time to implement and discuss inquiry-based instruction which inspired me to try them in my own classroom. Having lessons that were approved by the county and based on inquiry instruction, I had the tools immediately available so I was able to begin to change my teaching practices, while the inspiration was fresh.

At the same time I began working on a Master's degree at the local university. Within this program, there was an emphasis on science and mathematics education. Considering my most recent work experiences, I chose to focus on the science education. Within this program I was exposed to research and best practices that solidified my beliefs in the necessity of teaching science as inquiry. A key element of the program was expertise of the professors. One particular professor was passionate about science as inquiry and her dedication 
empowered me to model myself after her. During her class, the professor guided the class on standards based lessons using inquiry instruction. After modeling the process, she regularly would challenge the class to think more deeply about a particular point and after class expect us to reflect on the experiences. Seeing the professor walk to class lugging boxes of supplies so we had the opportunity to experience inquiry instruction, both as a student and teacher was a meaningful experience for me. In additional to the theory and experiences of using inquiry instruction she regularly addressed the practical issues of inquiry instruction such as time managements, buying and organizing of consumable supplies, administration support, or lack thereof, and communicating with colleagues about successful, and unsuccessful inquiry experiences. This professor provided the inspiration, guidance, and support that led me to commit to using inquiry instruction as a powerful tool in my classroom.

I taught elementary school, in various positions, for five years before beginning a master's program. During those years, I taught fourth and fifth grades in an affluent suburb of Fort Lauderdale, fifth grade in an affluent community in western Massachusetts, and K-5 science and fifth grade in an urban Orlando school. In Orlando, I taught at a low SES urban elementary school which had a large number of Latino students. This school had many of the often reported problems in some large urban school districts, substantial student mobility, limited parent support and involvement and students performing at low academic levels.

Using inquiry to teach science is driven by my personal belief that students in my classroom deserve the "best education "I can provide and I believe that inquiry instruction is a huge part of that "best education." Teaching is not about doing what is easiest or most comfortable for me, it is about inspiring my students to ask questions and seek answers to those questions while learning to believe in themselves. I want to inspire my students to find challenges exciting and look for opportunities to expand their understanding of their world. Science as inquiry, to me, is the best way for me to ignite a love of learning in my students.

My administration did not cheer my efforts, nor did they criticize them. I teach science as inquiry because it is the right thing to do. My administrators have faith that I will cover the mandated curriculum and if I choose to enhance my students' experiences in science, while still covering all the requirements, they trust my judgment. With science now being tested on state standardized tests, science classes are getting more attention from administration. However, they are not familiar enough with inquiry instruction or their own science understanding to demand inquiry instruction from all staff.

My success in teaching science as inquiry is completely student centered. Teaching science as inquiry is hard work and there are days when time and tempers are short. I have days when I simply feel too overwhelmed with student behavior, administrative requests, and life in general to teach using inquiry instruction and the easy way out is to assign text reading. Then, I think that the successes are my inspiration to keep going. There is the little girl that said, "I never liked science before this year, but now it's fun." There are the days when students notice science is not on the agenda and ask, "Why not?" There are the notes from parents thanking me for getting their child excited about school. A personal favorite was after a mealworm inquiry a parent sent a note describing her son's excitement over the inquiry. She said, "He was like a kid at Disneyland." Success like that is all the inspiration I need to keep using and improving my inquiry instruction.

\section{Martha's Beliefs}

Martha stated her science instruction beliefs during an interview, which centered on inspiring students to become life-long learners who asked their own questions and sought out information. She stated:

I believe teachers have an opportunity and an obligation to inspire and empower their students, especially in elementary science class. Ideally, I want students to feel personally changed by their experience in my classroom. Teaching is not about spouting information into students' heads that are waiting to be filled; rather it is the inspiration that creates life-long learners filled with curiosity. As students study science in my classroom, I want them to be inspired to ask questions, seek answers and share those ideas with others to complete the learning cycle. 
When describing her beliefs about the role of the teacher in the science classroom, Martha saw herself as a facilitator of student learning and linked students' success in science to the learning environment provided.

Teachers are the facilitators that maximize each student's ability to reach his/her personal best. Success in the science classroom is best reached through a learning centered environment that encourages sharing thoughts and idea in avenues such as small group discussion, guided inquiry experiments, full inquiry experiences and textbook support.

Martha rated herself as five (on a scale of 1 almost never to 5 almost always) when she responded to survey item one Part 2: "I am a facilitator of students learning."

Martha had strong convictions about the importance of providing students opportunity to participate in inquiry. She believed that the positive attitudes toward the study of science should be instilled in students early during their elementary school years:

It is my responsibility to ensure my students have the necessary experiences early and frequent exposure to an involvement with science that will help create a love of science and learning that will follow them throughout their lives.

Martha's response to why she chose to teach science using inquiry elucidated additional details about her beliefs about her role as the teacher in supporting student learning, guiding and providing explanations and explorations to students as they investigated science concepts, regardless of their academic ability. Martha stated:

Using inquiry allows students to become involved in science lessons in a way that engages all students, regardless of academic ability. Students' curiosity is sparked as they are presented scientific concepts to explore using hands-on involvement. Using inquiry affords students the opportunity to explore concepts and find, then share, their discoveries with classmates, which ultimately helps the student solidify their scientific learning. As their teacher, it is essential I support their learning by providing support, guidance, and explanations during explorations and discovery .

Martha was not typical as it related to elementary science teaching at her school. Many teachers at the school simply avoided teaching science and the principal did not emphasize science as a core subject that teachers needed to teach.

During an interview, the principal of the school was asked about her commitment as the leader of the school to science instruction and she stated, "When it is tested we will teach it." This comment followed the principal's detailed explanation about the time she wanted teachers to commit to reading and mathematics instruction at her school. Hence, Martha's commitment to science instruction was even more remarkable, since the principal's perspective was focused on teaching what is tested. Martha still managed to meet the principal's expectations for reading and mathematics instruction.

\section{Martha's Instructional Practices}

In addition to understanding Martha's beliefs about inquiry science instruction, this research aimed to elucidate what were her instructional practices and reasons for choosing to use inquiry in an urban low SES elementary classroom. An examination across data sources revealed that Martha was consistent in stating the importance of science teaching and her role in fostering a "love of learning in her students" as to why she chose to use inquiry practices. In an interview, Martha stated:

Exposing children to scientific process skills from an early age is essential in creating positive feelings toward the study of science. If children are frequently engaged in science lessons which probe for deeper understanding of science concepts the foundations for life-long learning is set. Actively participating in science lessons is a critical aspect for building the basis for future learning. 
Martha chose to use inquiry along with other methods during science instruction because she believed that "elementary students were being exposed to science for the first time and it was the teacher's role to inspire the desire to constantly seek more knowledge." In addition, she expressed her personal feelings about affecting student learning: "I am passionate about finding the most effective ways of stimulating and sustaining the love of learning in my students."

As an elementary science teacher, Martha's instructional practices also included other approaches and resources. The textbook was viewed as a resource and not the center of science instruction. These conclusions were further supported in the teacher's responses to inquiry survey item 7: "I do not depend on the textbook." Martha self-rating was that she seldom used the textbook. Furthermore, classroom observations supported Martha's statement about not being dependent on the textbook during science instruction. She did use a number of hands-on and/or inquiry based activity sheets during science instruction.

This research revealed that Martha's inquiry practices were facilitated by the use of a variety of curricula materials: 1) school district provided science curricula (district developed science lessons) which often followed the 5-E model (engage, explore, explain, extend/apply, evaluation, or less often full and guided inquiry, and 2) teacher selected worksheets which included several different science process skills in the lesson format and/or were mostly structured inquiry lessons.

Martha consistently taught science a minimum of three times a week from 45 to 60 minutes per lesson. The amount of time Martha committed to science instruction was in itself commendable and not the norm at her school.

\section{Martha- An Inquiry Lesson}

The following example documents Martha's inquiry practices were further documented when teaching lessons in the unit, "Living Things and Their Environment." The inquiry lesson described below was titled: "Can Seeds Germinate Without Soil?" This seven-day inquiry lesson provided students the opportunity to investigate factors that affected plant growth beginning from seeds. In her reflection, Martha stated the focus of the lesson was, to give students the freedom for the first time to generate and carry out their own testable questions. The following exchange occurred during an observation:

Zane: No, I don't suppose that an organic organism may germinate without soil. First, because the soil helps fertilize the plant. Second, because it gives the roots an area to hold onto. Finally, it will give the roots water and nutrients they need.

Malos: The seeds can't germinate because soil has the nutrients.

Martha: Thank you for your wonderful thinking. Now, is this a testable or researchable question?

Class: Testable.

Martha: Terrific!

During this exchange, Martha did not see the need to probe students' thinking deeply, nor did she address their concepts of seed germination. She decided to focus on whether or not students could test their ideas. Next, Martha had students participate in a follow-up activity called, "All Write." In this activity everyone gets to participate by writing their ideas down on paper. First, students were instructed to think about how they could design an experiment to test the ideas that seeds need soil. Then they were to use pictures and words to explain how the experiment should be designed. Martha asked students if they had any questions, to which they responded, "no." Then Martha instructed students to begin.

Once students had completed their designs, Martha asked for whole class sharing of ideas. Students had been supplied baggies to use as containers for their seeds. Most of the student's responses centered on putting the seed in one baggie with dirt and in different baggies put the seed with nothing but water. Martha commended students on their ideas. Then she also suggested that students use pseudo soil (wet paper towels) 
as a third baggie experiment. Students were then given 10 minutes to build their experiments. It actually took the students 15 minutes but in all they did finish their designs. After baggies were prepared and sealed students drew on their data collection sheets observations for day one. For the next seven school days students observed, and documented what occurred with their seeds.

Overall, Martha was pleased with this inquiry for she believed that it facilitated students' learning and formulating conclusions. Students were shocked to see that the most conducive environment for the seeds to sprout was the pseudo soil. Not only did the seeds germinate, in two cases, the seedlings actually popped out the baggie. Hence, their results contradicted their predictions.

The two students whose seeds had the most growth were particularly proud of themselves and were very excited to share their thoughts on why their seedlings grew so well. The two students actually had the idea to transplant their seedlings into a paper cup with dirt to see if they would continue to grow. The transplanted seeds were left over a long weekend. Upon their return, the seedlings had grown so tall that they flopped over the side of the cup. The student scientists could not let their little plants die, so they took pencils, without help or suggestion from the teacher, and used string to tie their plants to the pencils for support. At this point, Martha believed the plants might grow to full size, so she sent the plants home with the two students.

During this inquiry, Martha and her students also learned a few procedural details too. They put the seeds into a baggie of water, which was fine, as long as the baggie remains sealed. The students enjoyed watching the seed coat peel off the plant and were a bit sad to see the seeds die, but one real lesson learned by all, teacher included, was rotten seeds stored in baggies of water have a terrible odor! Once the baggies were opened to more closely examine the seeds, the stench quickly filled the classroom and the students were not shy about bemoaning the fact that their noses were assaulted by the smell.

Martha stated that the inquiry was memorable. She believed it was a great experience for students to see that the smelly seeds caught her off guard and for the students to be able to experience doing science first hand. As they did this inquiry, they learned that things may develop differently than anticipated, but continue to observe, record, and draw conclusions from the experience was the best part of learning.

Because this inquiry occurred in the spring of the school year, students were very familiar with being able to plan their own investigations. Martha commented about the design of the inquiry:

Having two baggies to compare was adequate, but the next time I lead this inquiry, I will add one more baggie containing a different mixture. By adding a third mixture to the inquiry I can advance students' thinking by having them classify similarities and differences of the baggies as they observe which are suitable for plant growing and which are not. Having a third baggie may also help students distinguish the importance of variables in the inquiry, because up to this point in their school year, identifying variables was still tricky for some students .

\section{Discussion and Conclusions}

An examination of the case study data elucidated findings concerning Martha's beliefs and use of inquiry practices. Martha's beliefs and practices did align and her professional preparation influenced her use of inquiry substantially. The alignment of beliefs and practices has been reported to be beneficial when facilitating inquiry instruction (Author, 2006). Martha identified two events that help shaped her use of inquiry: 1) district provided workshops on using 5-E model and 2) university Master's program in science and mathematics where the professor showed and eagerness for teaching science as inquiry and modeled its use. Martha saw herself as a facilitator of student learning and believed that it was her responsibility to affect positive attitudes in all of her urban low SES students toward science during their elementary school years, regardless of ability. Martha also reflected on her practice and looked for opportunities to improve her use of inquiry. 
Like a number of elementary teachers, Martha did not believe that she could teach science well and lacked the confidence to do so. She sought out needed professional development and extended learning experiences through a Master's program where she could continue to develop her understanding of inquiry while learning additional science and mathematics content. She believed that this was extremely beneficial to her continued use of inquiry in the classroom. Martha explicitly stated that the instructor's modeling of inquiry and apparent excitement about teaching science using inquiry made a positive impact on her teaching practices. Martha's experiences show that university level science educators have power to help shape and mold how our students think about their own teaching.

As we examine reform teaching practices, such as inquiry, it is important that teachers have continuous ongoing professional development to support them. Opfer and Pedder (2011), argue that conceptualizing teacher professional learning as key and is advanced as a complex interactive interaction of the teacher, the school and the learning activity. I would add that university teacher education programs are also major players in sustaining the quality and nature of science teachers' professional development. Martha was extremely positive about the inquiry learning experiences saying that they really helped her to venture out and do inquiry with her students. As a science education community, we need to make sure that we not only model "best practices in science instruction" but also partner with local school district curriculum personnel to assist them in providing professional development opportunities focused on science reform instructional practices, like inquiry, as a means to support teachers' use of inquiry with their students.

In response as to why she chose to teach science using inquiry Martha believed that inquiry allowed students to become involved in the lessons and it was essential that she facilitate their learning by providing support, guidance, and explanations during explorations and discoveries. Martha's perspective on teaching inquiry aligns with other teachers. Kazempour and Amirshokoohi, (2014) found that their "participants discussed the importance of motivating students by engaging them in inquiry-based, student-centered, contextualized and relevant learning opportunities" (p. 302). This is important because Martha taught in an urban low SES elementary school and these schools are often depicted as having an array of problems, including poor pedagogy (Haberman, 1990; Rist, 2017) Also, teachers in these low SES schools have their own set of distinct challenges. It has been reported that teachers within these larger urban schools in lower SES communities tend to develop a lesser "sense of community" among each other than do other schools (Brik and Driscoll, 1988). Therefore, it is encouraging that Martha not only sought to improve her inquiry teaching practices but was committed to providing inquiry learning experiences to her students. Martha did not always guide students to deeper understanding of the science content under study, nor did she always provide students with direct answers to their questions. Rather, she often attempted to use guiding and follow-up questions when facilitating inquiry experiences. She sought to increase students' interest in and experiences with doing science. Martha's beliefs about teaching science as inquiry to all of her students was supported by her classroom instructional practices.

Martha provided her students with a number of opportunities to participate in structure and guided inquiry and hands-on activities. She did not depend on the textbook as a resource, but she did use a number of commercially produced inquiry activities and school district- developed inquiry-based activity packets.

Rist (2017) asks very specific question about teachers in urban schools- their quality, their longevity, and their intentions towards the poor. The question is very straight forward, "Who wants to teach in urban schools and why?" (p.20). Martha was aware of the challenges she faced in her urban elementary school; yet , Martha's actions demonstrated that she enjoyed teaching inquiry-based science to her students. Urban schools often have what may seem as insurmountable problems, but Martha was positive about her experiences. Martha believed that she could make a difference. She sought out additional professional development and started a master's degree program that focused on improving elementary teachers' science and mathematics content knowledge. 
Stevens (1993) argues that "current teaching practices in many urban school classrooms have been responsible for keeping the academic achievement of poor and minority students at a very low level" (p. 273). These teachers' practices that do not uphold high academic standards for their urban minority students, may, in part be due to their own feeling of lack of preparedness to teach elementary science. In a 2013 survey, Horizon Research, Inc. found that only 39 percent of elementary teachers feel very well prepared to teach science (p.7). In Martha's case, she countered this trend. She took advantage of professional development opportunities and started a master's program to improve herself. Also, she sought to provide her students with a wide array of science experiences through reform science instructional methods. Martha's practices and espoused beliefs support that she enjoyed teaching inquiry to her students and was committed to providing them with learning experiences to increase their interest in science. Central to Martha's inquiry instruction was to focus on students' learning needs. She reflected after the conclusion of one inquiry experience:

The lesson learned for me is I must work on keeping my goals focused around student learning. Rescheduling an inquiry is far better than rushing to finish one and cross it off the lesson plan. If one takes the time to plan and inquire then it is a disservice to the students to not implement it correctly.

Martha was student centered. Alkove and McCarty (1992) argued that "constructivist teachers believe learning in school should be student-centered as opposed to teacher-centered" (p. 20). Other researchers (Furtak, Seidel, Iverson, \& Brigs, 2012) concur with Alkove and McCarty (1992) that the teacher is very important and should actively guide student activities in the context of inquiry learning. The previous descriptions of Martha's inquiry practices show that gets it. She played a crucial role in facilitating students' learning through inquiry.

For Martha, time was sometimes a hindrance to the implementation of an effective inquiry and she often had to focus on the end product of the activities and not processes. Both time and focus on learning goals have been identified as hindrances to effective inquiry. Horizon Research (2013) reported that in our nation's elementary schools, on average, allocate 20 minutes of the school day on science instruction. This is disturbing for those of us who believe science instruction is important in our schools and students in low SES urban schools need to have high quality, consistent science instruction. Yet, on a brighter note, for Martha, student learning was most important and she was driven to provide her students with an array of inquiry experiences. Martha concluded: "I am passionate about finding the most effective ways of stimulating and sustaining the love of learning in my students." Martha was motivated to teach science and to use inquiry practices during science instruction with her low SES urban students. She believed that they could learn science through inquiry. As evident by Martha's beliefs and practices, how teachers perceive their role as science teachers may have profound effects on what they do. Martha sought to increase students' interest in and experiences with doing science. And what was evident in this study was that she used an array of inquiry-based resources to facilitate the implementation of inquiry practices. Therefore, teacher educators and professional development providers should provide the kinds of inquiry activities that best support teachers' use of inquiry practices in K-12 classrooms as described in the National Science Education Standards (NRC, 1996) and also the Next Generation Science Education Standards (2013). We should construct course work and professional development opportunities for teachers centered on their learning to teach using inquiry methods and provide extended support through developing relationships with school district science curriculum personnel so that teachers can get the reinforcement they need to keep using inquiry once they begin working in their respective schools. Teachers should be supported as they do inquiry such that they develop what Dewey (1910) called, "a mode of intelligent practice and a habitual disposition of mind" (p.124), so that all learners benefit from rich, challenging science experiences, including those in urban low SES schools.

\section{Acknowledgements}

The preparation of this manuscript was funded by a grant from the National Science Foundation (NSF, Grant REC-0447676). 


\section{References}

Abell, S., \& Smith, D. (1992). What is science? Pre-service elementary teachers' conception of the nature of science. In S. Hills (Ed.). Proceedings of the Secondary International and Philosophy of a Science Teaching Conference (p.11-12). Kingston, Ontario, Canada Queen's University.

Alkove, L., \& McCarty, B. (1992). Plain talk: Recognizing positivism and constructivism in practice. Action in Teacher Education, 14(2), 16-22.

Burry-Stock, J. (1999). ESTEEM instrument. Western Michigan, University, Kalamazoo, MI: CREATE.

Brand, B. R., \& Glasson, G. E. (2004). Crossing cultural boarders into science teaching: Early life experiences, racial and ethnic identities, and beliefs about diversity. Journal of Research in Science Teaching, 41(2), 119-141.

Brink, A.S., \& Driscoll, M.E. (1988). The high school as community centered influences and consequences for students and teacher. Madison Wisconsin: National Center on Effective Secondary Schools.

Bryan, L. A. \& Abell, S. K. (1999). The development of professional knowledge in learning to teach elementary science. Journal of Research in Science Teaching, 36, 121-139.

Dewey, J. (1910). Science as subject-matter and as method. Science, 121-127.

Furtak, E.M., Seidel, T., Iverson, H., \& Briggs, D.C. (2012). Experimental and quasi-experimental studies of inquiry-based science teaching a meta-analysis. Review of Educational Research, 82(3), 300-329.

Haberman, M. (1991). The pedagogy of poverty versus good teaching. Phi Delta Kappan, 73(4), 290-294.

Haggerty, S. (1992). Student teachers' perception of science and science teaching. In S. Hills (Ed) Proceedings of the Secondary International and Philosophy of a Science Teaching Conference (p.11-12). Kingston, Ontario, Canada Queen's University.

Hewson, P., \& Hewson, M. G. A. (1989). Analyses and use of a task for identifying conceptions of teaching science. Journal of Education for Teaching, 15, 191-209.

Horizon Research, Inc. (2013). 2012 National survey of science and mathematics: Highlights Report. Chapel Hill, NC. Author.

Huber, R. A., \& Moore, C. (2001). A model for extending hands-on science to be inquiry based. School Science and Mathematics, 101(1) 32-42.

Jasalavich, S. (1992). Preservice elementary teachers' beliefs about science teaching and learning and perceived sources of their beliefs prior to their first formal science teaching experience. Paper presented at the annual meeting of the National Association for Research in Science Teaching, Boston, MA. March.

Janpierre, B. (2006.) What teachers report about their inquiry practices. The Journal of Elementary Science Education, 18(1), 57-68.

Kaymakaoglu, S. E. (2018). Teacher's beliefs, perceived, practiced and actual classroom practices in relation to traditional (teacher-centered) and constructivist (learner-centered) teaching. Journal of Education and Learning, 7(1) 31-37.

Kazempour, M., \& Amirshokoohi, A. (2014). Transitioning to inquired-based teaching: Exploring science teachers' professional development experiences. International Journal of Environment and Science Education, 9(3), 285-309.

Keys, C. W. \& Bryan, L. A. (2001). Co-constructing inquiry-based science with teachers: Essential research for lasting reform. Journal of Research in Science Teaching, 38(6), 631-645.

Lawrenz, F. (1986). Misconceptions of physical science concepts among elementary school teachers. School Science and Mathematics, 86(4), 1213-1214.

Leonard, J. Barnes-Johnson, J, Dantley, S. J. \& Kimber, C. (2011). Teaching science inquiry in urban contexts: The role of elementary pre-service teachers' beliefs. Urban Review, 42, 124-150. 
Lorsbach, A. (1992). An interpretive study of prospective teachers' beliefs about the nature of science. Paper presented at the annual meeting of the National Association for Research I Science Teaching, Boston.

Lotter, C., Thompson, S., Dickenson, T., Smiley, W. Blue, G. \& Rea, M. (2018). The impact of practices teaching professional development model on teachers' inquiry instruction and inquiry efficacy beliefs. International Journal of Science \& Mathematics Education, 16(2) 255-273.

NGSS Lead States. (2013). Next Generation Science Standards: For states, by states. Washington, DC: National Academies Press.

National Science Research Council. (2011). A Framework fork-12 Science Education: Practices, Crosscutting Concepts, and Core Ideas. Washington, DC: National Academy Press.

National Science Research Council. (1996). National Science Education Standards. Washington, DC: National Academy Press.

Nespar, J. (1987). The role of beliefs in the practice of teaching. Journal of Curriculum Studies, 19, 317-328.

Norman, O., Ault, C. R., Nentz, B., \& Meskimen, L. (2001). The black white "achievement gap" as a perennial challenge of urban science education: A sociocultural and historical overview with implications for research and practice. Journal of Research in Science Teaching, 38(10), 1101-1114.

O'Laughlin, J. (1990). Evolving beliefs about teaching and learning, the view from Hofstra University: A perspective on teachers' beliefs and their effects. Paper presented at the annual meeting of the American Educational Research Association, Boston.

Opfer, V.D., \& Pedder, D. (2011). Conceptualizing teacher professional learning, Review of Educational Research, 81(3), 376-407.

Pajares, M. F. (1992). Teachers' beliefs and educational research: cleaning up a messy construct. Review of Educational Research, 62, 307-332.

Parke, H. M..., \& Coble, C. R. (1997). Teachers designing curriculum as professional development: A model for transformational science teaching. Journal of Research in Science Teaching, 34, 773-789.

Pennuel, W. R., \& Fishman, B. J. (2012). Large scale science intervention research we can use. Journal of Research in Science Teaching, 49(3), 281-304.

Richardson, V. (1996). The role of attitudes and beliefs in learning to teach. In J. Sikula. (Ed.), Handbook of research on teacher education (pp.102-119). New York: Macmillan.

Rist, R. (2017). The urban school: Factories for failure. New York, NY: Routledge.

Schwab, J., \& Brandwein, P. F. (1996). The teaching of science of as enquiry. Elements in a strategy for teaching science in the elementary school. Cambridge, Massachusetts: Harvard University Press.

Stevens, F. I. (1993). Applying an opportunity-to-learn conceptual framework to the investigation of the effects of teaching practices via secondary analyses of multiple-case study summary data. Journal of Negro Education, 62(3), 232-248.

Yin, R. (1989). Case study research: Design and methods. Beverly Hills, CA: Sage Publication.

Yin, R. (2015). Qualitative research from start to finish. New York, NY: Guilford Publications 


\section{Appendix A: Examples of ESTEEM Instrument Items}

Please use the indicated ratings to describe your teaching practices and beliefs.

$5=($ almost always $), 4=$ (often), 3-(sometimes), 2-(seldom), 1-(almost never)

1. Your students are responsible for their own learning. $\quad 12345$

2. Your students actively engaged in initiating experiences.

3. Your students are actively engaged in asking

12345 questions throughout class-time. 